\title{
Pemahaman Konsep IPA Siswa SMP Melalui Pembelajaran Problem Solving pada Topik Perubahan Benda-Benda di Sekitar Kita
}

\author{
Ikhwan Khairu Sadiqin ${ }^{1}$ *, Uripto Trisno Santoso ${ }^{1}$, Arif Sholahuddin ${ }^{1}$ \\ ${ }^{1}$ Program Studi Magister Keguruan IPA, Universitas Lambung Mangkurat. Jalan Brigjen H. Hasan \\ Basri No. 87, Banjarmasin 70124, Kalimantan Selatan, Indonesia. \\ * Corresponding Author. Email: ksikhwan@ gmail.com, Telp: +62257-560115 \\ Received: 14 January 2017; Revised: 8 May 2017; Accepted: 18 May 2017
}

\begin{abstract}
Abstrak
Penelitian bertujuan untuk mendeskripsikan pemahaman konsep IPA siswa SMP dan kemampuan menalar dalam membentuk konsep melalui pembelajaran problem solving. Jenis penelitian adalah deskriptif kuantitatif. Teknik pemilihan sampel dilakukan secara purposive sampling menyesuaikan dengan jenjang umur studi PIRLS, TIMSS dan PISA. Sampel penelitian adalah siswa kelas VII berjumlah 66 orang berasal dari SMP unggulan di Banjarmasin. Data penelitian diperoleh menggunakan instrumen tes. Teknik analisis data dengan cara melihat perkembangan skor $n$-gain dari pemahaman konsep dan rata-rata skor kemampuan menalar siswa pada tiap pertemuan. Hasil penelitian diperoleh rata-rata pemahaman konsep siswa sebelum pembelajaran adalah 52,28 tergolong kategori kurang baik, skor setelah pembelajaran adalah 77,40 tergolong kategori baik. Kemampuan menalar siswa dalam mengamati objek, abtraksi dan diskriminasi, dan penetapan aturan masalah tergolong sangat baik. Pemahaman konsep IPA dan kemampuan menalar berkembang dengan model problem solving. Perkembangan terjadi karena siswa terlatih dalam proses memilah dan menghubungkan pengetahuan deklaratif dan prosedural ketika menyelesaikan masalah pembelajaran.
\end{abstract}

Kata Kunci: problem solving, pemahaman konsep, pengetahuan deklaratif, pengetahuan prosedural, perubahan benda-benda di sekitar kita

\section{Junior High School Students' Natural Science Conceptual Understanding through Problem Solving Learning on the Topic of the Change of the Things around our Life}

\begin{abstract}
The study aimed to describe the understanding of science concept of junior high school students and the ability of reasoning through problem solving learning. The research is descriptive quantitative. The sample selection technique was conducted by purposive sampling according to the age of study of PIRLS, TIMSS and PISA. The sample are 66 students of grade VII from Junior High School in Banjarmasin. The research data was obtained using the test instrument. Data analysis technique by analyzing the development of $n$-gain score of conceptual understanding and average score of students' reasoning ability at each meeting. The result of the research shows that the average of the students' understanding before the learning is 52.28 is categorized as low, the score after learning is 77,40 belong to good category. The students' reasoning ability to observe objects, abstraction and discrimination, and the determining of problem rules categorized as very good. Science conceptual understanding and the ability of reasoning has evolved with the problem solving model. Development occurs because students are trained in the process of sorting and linking declarative and procedural knowledge when solving learning problems.
\end{abstract}

Keywords: problem solving, conceptual understanding, declarative knowledge, procedural knowledge, changes things around us

How to Cite: Sadiqin, I., Santoso, U., \& Sholahuddin, A. (2017). Pemahaman konsep IPA siswa SMP melalui pembelajaran problem solving pada topik perubahan benda-benda di sekitar kita. Jurnal Inovasi Pendidikan IPA, 3(1), 52-62. doi:http://dx.doi.org/10.21831/jipi.v3i1.12554

Permalink/DOI: http://dx.doi.org/10.21831/jipi.v3i1.12554 
Jurnal Inovasi Pendidikan IPA, 3 (1), 2017 - 53

Ikhwan Khairu Sadiqin, Uripto Trisno Santoso, Arif Sholahuddin

\section{PENDAHULUAN}

Tatanan masyarakat dunia abad 21 menghendaki insan yang unggul dibidang sains. Pendidikan abad ke-21 tidak terfokus lagi dalam hafalan materi bidang kajian (core subjects), tetapi juga memberikan penekanan pada kecakapan hidup (life skills), keterampilan belajar dan berpikir (learning \& thinking skills), literasi dalam teknologi informasi dan komunikasi (ICT literacy). Terjadi transformasi paradigma pendidikan yang mendambakan lahirnya generasi muda berpola pikir layaknya ilmuwan (OECD, 2016, p.8). Generasi yang kritis yang tidak serta merta menerima pengetahuan yang diberikan tetapi juga memahami proses didapatkannya.

Keberhasilan tatanan masyarakat suatu negara bisa dinilai dari prestasi siswa di sekolah (Tafsir, 2012, p.82). Kemampuan sains siswa dunia merujuk pada studi sejenis PIRLS (Progress in International Reading Literacy Study), PISA (Programme for International Student Assessment) dan TIMSS (Trends in International Mathematics and Science Study). Ketiga studi tersebut cenderung mengukur kemampuan siswa pada periode peralihan operasional konkret menuju formal, umumnya pada kelompok umur SMP (Sekolah Menengah Pertama).

Berdasarkan laporan Pusat Penilaian Pendidikan Badan Penelitian dan Pengembangan Kemendikbud oleh Setiadi, et.al., (2012, p.105) pada studi PIRLS siswa berada pada posisi 41 dari 45 negara. Senada dengan TIMSS 2011, peringkat 40 dari 42 negara. Perolehan pada ajang PISA 2015 berada pada peringkat 69 dari 76 negara. Pemerintah menyadari bahwa capaian dewasa ini masih belum membanggakan (Kemendikbud, 2013, p.5).

Wasis (2015, p.8) menganalisis capaian kurang memuaskan disebabkan karena siswa hanya berhasil menyelesaikan permasalahan yang sudah dikenal, dengan informasi pendukung yang telah tersedia. Fakta tersebut menunjukkan bahwa siswa Indonesia hanya mampu menyelesaikan routine problem (permasalahan rutin) dan mengalami kesulitan ketika menghadapi masalah nonroutine problem (permasalahan non rutin).

Kesulitan meliputi pemecahan masalah melalui penalaran dalam soal pengamatan tentang konsep sains. Siswa hanya mampu memahami beberapa fakta terkait konsep dasar fenomena alam. Belum mampu melaporkan dan menghubungkan berbagai konten pengetahuan, apalagi menerapkan konsep-konsep yang kompleks dan abstrak.

Berdasarkan analisis kurikulum SMP, topik perubahan benda-benda di sekitar kita merupakan bahasan pada mata pelajaran IPA yang menampilkan banyak pengetahuan konsep berbasis masalah. Kurikulum memuat konten pengetahuan konsep berupa konsep perubahan fisika, konsep perubahan kimia dan pemisahan campuran. (Kemendikbud, 2014, p.143). Konsep-konsep tersebut saling terkait sehingga memerlukan keterampilan melakukan penalaran agar siswa dapat memahaminya secara utuh.

Pangkal masalah berdasarkan sudut pandang instructional design adalah guru kesulitan merancang dan melaksanakan proses pembelajaran yang dapat membangun pemahaman konsep siswa melalui kegiatan pemecahan masalah yang runtut (Arafah \& Sihes, 2015, p.19). Guru terkendala dalam memilih dan menerapkan strategi pembelajaran yang ingin diterapkan. Ketika mencoba suatu model atau strategi, timbul keraguan tentang keberhasilan pelaksanaan pembelajaran dan kemampuan siswa dalam beradaptasi.

Guru mengalami kesulitan dalam mengajarkan konsep baru yang sebagian besar belum dikenal siswa. Kendala lain adalah dalam mengaitkan konsep-konsep tersebut menjadi konsep yang baru atau lebih kompleks. Guru sering kewalahan untuk menuntun siswa membangun pengetahuan konsep dalam suatu kegiatan belajar yang terstruktur. Siswa menjadi jarang dilatih menghubungkan pengetahuan dalam membangun sebuah konsep.

Umumnya siswa gagal dalam dua proses. Proses pertama adalah dalam mendefinisikan masalah. Hal ini terkait dengan sifat konten yang belum pernah dikenal siswa sebelumnya, seperti sifat fisika dan sifat kimia. Konten ini merupakan pengetahuan prasyarat untuk dapat memahami konsep perubahan fisika, konsep perubahan kimia dan pemisahan campuran (Kemendikbud, 2014, p.143). Proses lain yang menjadi kendala siswa adalah ketika menjembatani antara pengetahuan prasyarat yang didapat siswa dengan masalah pembelajaran.

Kendala guru dan kegagalan siswa tersebut menyebabkan pemahaman konsep siswa menjadi rendah. Pemahaman konsep memiliki definisi beragam, tergantung dari bidang kajian ilmu masing-masing. Holme, Luxford, \& Brandriet (2015, p.1479) menyimpulkan definisi pemahaman konsep dalam konteks IPA berdasarkan pendapat para pakar adalah kemampuan 
Jurnal Inovasi Pendidikan IPA, 3 (1), 2017 - 54

Ikhwan Khairu Sadiqin, Uripto Trisno Santoso, Arif Sholahuddin

siswa dalam memahami hubungan konsep satu sama lain sehingga bisa diterapkan untuk memecahkan masalah. Pemahaman konsep yang kurang mapan dapat ditandai dengan tidak memahami makna konten pengetahuan, definisi, dan alasan dari bagian pengetahuan yang saling terkait.

Faktor pemicu rendahnya pemahaman konsep adalah siswa tidak diberi praktik yang cukup untuk menyelesaikan masalah pembelajaran pada masa lampau (Jacobsen, Eggen, \& Kauchak, 2009, p.251). Siswa menjadi tidak terbiasa menghubungkan pengetahuan masa lampau dan pengetahuan yang baru didapat. Siswa juga kesulitan dalam memilah pengetahuan yang diperlukan dalam operasi pemecahan masalah pembelajaran. Hasilnya siswa mengalami kesulitan dalam memahami konsep yang sedang diajarkan.

Solusi paling konkret untuk mengatasi masalah yang dialami guru dan siswa adalah mengenalkan model pembelajaran yang dapat diaplikasikan guru sehingga memberikan kesempatan siswa membangun pemahaman konsep melalui proses pemecahan masalah. Gupta, Kavita \& Pasrija (2016, p.37) menemukan bahwa problem solving merupakan komponen kunci dalam keberhasilan prestasi siswa. Menguatkan saran Kemendikbud (2014, p.144) bahwa untuk mengajarkan topik perubahan benda-benda di sekitar kita sebaiknya siswa diarahkan melakukan kegiatan pemecahan masalah melalui observasi dan berdiskusi dengan teman kelompoknya dalam proses menemukan konsep.

Berdasarkan pendapat para ahli, penerapan model problem solving dapat mengembangkan pengetahuan siswa dalam melakukan penalaran. Sejalan dengan usulan Arends (2012, p.289) bahwa pembelajaran berdasarkan masalah mendorong siswa menyusun pengetahuan dan mengembangkan penalaran terhadap masalah yang sedang dikaji. Relevan dengan tujuan utama model tersebut yakni, memecahkan masalah dan memahami konsep yang ada dibalik masalah tersebut (Jacobsen et.al., 2009, p.250).

Jacobsen et.al. (2009, p.249) mengemukakan model problem solving merupakan sarana yang tepat memberikan pengalaman pemecahan masalah secara terstruktur kepada siswa. Problem solving adalah pengajaran berbasis masalah dimana guru membantu siswa merasakan pengalaman langsung belajar memecahkan masalah secara aktif dalam kelompok. Langkah-langkah problem solving meliputi siswa dibimbing guru untuk mengidentifikasi masalah, menegaskan masalah, memilih strategi yang tepat, melaksanakan strategi yang telah disepakati bersama dengan berdiskusi, dan mengevaluasi hasil pemecahan masalah.

Peran utama guru memberi siswa tanggung jawab untuk memecahkan suatu masalah. Guru membantu memberikan pengalaman yang konkret seperti praktikum atau penyelidikan, tergantung masalah yang diajukan. Guru berperan secara tidak langsung dengan memberikan pertanyaan-pertanyaan yang jawaban mengarahkan siswa agar dapat mengolah pengetahuan yang diperlukan untuk memecahkan masalah.

Keunggulannya adalah siswa terbiasa memecahkan masalah. Siswa yang terbiasa memecahkan masalah terlatih menyerap pengetahuan secara utuh. Artinya pemahaman siswa tidak hanya dengan hafalan atau jawaban akhir, tetapi juga proses pemahaman itu bisa didapat.

Sejalan dengan teori Jerome Bruner bahwa pengetahuan pada pembelajaran problem solving menjadi bermakna karena siswa berusaha mencari pemecahan masalah dan pengetahuan yang menyertainya sehingga menghasilkan pemahaman yang berkesan. Dampaknya adalah meningkatkan penalaran dan pemahaman konsep siswa (Dahar, 2011, p.80).

Mengacu pada hasil penelitian terdahulu problem solving merupakan model pembelajaran yang sesuai untuk membantu siswa dalam membangun pemahaman konsep. Pembelajaran dapat diterapkan pada jenjang SMP, aktivitas guru dan siswa terlaksana dengan baik (Sadiqin, 2016a, p.230). Pemahaman IPA pada siswa usia operasional konkret menuju formal menjadi optimal (Capobianco \& Tyrie, 2009, p.1). Proses pemecahan masalah tersebut berpengaruh signifikan terhadap perkembangan intelektual siswa (James, 2012, p.169). Pemahaman konsep mengalami peningkatan karena kemampuan menalar siswa berkembang (Ali, Hukamdad, Akhter, \& Khan, 2010, p.67; Coştu, 2008, p.3; Jackson \& Martin, 2014, p.18; Nfon, 2013, p.38; Perveen, 2010, p.9; Sadiqin, 2015, p.1302).

Berdasarkan latar belakang tersebut maka penelitian ini bertujuan untuk mendeskripsikan pemahaman konsep IPA siswa SMP dan kemampuan menalar dalam membentuk konsep melalui pembelajaran problem solving. Jenis penelitian adalah deskriptif kuantitatif.

\section{METODE}

Penelitian ini tergolong deskriptif kuantitatif. Penelitian deskriptif bertujuan untuk 
memberi gambaran perihal keberadaan suatu variabel, berupa fenomena lapangan (Sugiyono, 2012, p. 35). Fungsinya untuk menganalisis pemahaman konsep IPA siswa melalui model problem solving. Analisis juga membahas lebih dalam tentang kemampuan menalar siswa dalam membentuk pemahaman konsep. Pembahasan disajikan secara deskriptif kualitatif berdasarkan dari data kuantitatif, yakni pemahaman konsep dan kemampuan menalar siswa.

Lokasi penelitian bertempat di SMPN 1 Banjarmasin dan SMPN 1 Banjarbaru provinsi Kalimantan Selatan pada jenjang kelas VII. Penelitian dilaksanakan pada semester ganjil tahun pelajaran 2015/2016.

Populasi adalah siswa SMP unggulan di kota Banjarmasin. Sampel berjumlah 66 orang. Teknik pemilihan sampel dilakukan secara purposive sampling dengan mempertimbangkan kesesuaian karakteristik siswa, kurikulum dan tujuan penelitian. Sampel meliputi 32 orang siswa kelas VII SMPN 1 Banjarmasin dan 34 orang siswa kelas VII SMPN 1 Banjarbaru.

Karakteristik siswa yang diharapkan adalah setara dengan tingkat umur studi PIRLS, PISA, dan TIMSS. Siswa pada periode peralihan operasional konkret menuju formal. Sampel penelitian pada umumnya berumur antara 11 tahun sampai 13 tahun.

Jenjang usia ini adalah periode awal seseorang siswa dapat diajarkan memecahkan masalah dengan cara menalar dalam membentuk pemahaman konsep. Berdasarkan teori perkembangan kognisi piaget siswa tersebut mengalami peralihan pola pikir siswa sedikit demi sedikit dari pola pikir yang sangat bersifat kontekstual menuju kepada penalaran hipotesis deduktif (Slavin, 2011, p.108).

Lebih lanjut Piaget menemukan bahwa penggunaan operasi formal bergantung pada ketidakasingan siswa dengan mata pelajaran tertentu. Ketika siswa merasa tidak asing dengan suatu mata pelajaran, mereka lebih mungkin menggunakan operasi formal melalui. Mempertimbangkan hal tersebut dalam pembelajaran IPA siswa sudah bisa diajarkan konsep materi konkret juga ditunjang oleh kegiatan memecahkan masalah dalam model problem solving sebagaimana dalam studi PIRLS, PISA, dan TIMSS.

\section{Prosedur}

Sebelum pembelajaran siswa mengikuti tes pemahaman konsep. Tes awal berfungsi untuk mengetahui pemahaman konsep siswa sebelum dilakukan pembelajaran problem solving. Kegiatan belajar mengajar topik perubahan benda-benda di sekitar kita dilakukan dalam 3 kali tatap muka.

Kegiatan pembelajaran yang dilakukan meliputi pengamatan perubahan fisika dan perubahan kimia terhadap benda-benda dalam kehidupan sehari-hari dan kegiatan industri. Aktivitas meliputi melakukan percobaan berbagi metode pemisahan campuran, berdiskusi, dan membuat tulisan dari berbagai pengamatan yang dilakukan. Kegiatan pembelajaran secara umum meliputi hasil pengamatan yang dilakukan siswa, demonstrasi awal sebagai pengantar yang dilakukan guru, serta diskusi kelas secara berkelompok (Kemendikbud, 2014, p.143).

Tes lainnya setelah tatap muka ketiga. Tes akhir berfungsi untuk memberi gambaran hasil belajar dari pembelajaran problem solving. Sebagai pembanding untuk meninjau keadaan awal dan keadaan akhir skor pemahaman konsep siswa. Berdasarkan data penelitian tersebut dibahas secara deskriptif tentang capaian belajar siswa dan proses berpikir yang terjadi dari sudut pandang psikologis.

\section{Data, Intrumen, dan Teknik Pengumpulan Data}

Instrumen penilaian pemahaman konsep menggunakan teknik tes, yaitu paper based test. Soal berupa pilihan ganda dan essay. Pengukuran dilakukan dengan teknik prestest dan posttest. Teknik wawancara diberlakukan sebagai pelengkap untuk mencari tahu alasan psikologis tertentu yang menjadi dasar pengambilan keputusan dari sudut pandang siswa.

Sebelum dilakukan penelitian instrumen pemahaman konsep telah terlebih dahulu berhasil melewati proses validasi oleh pakar. Validitas tes yang dilakukan adalah validitas isi (content validity). Validasi isi memiliki tujuan supaya konten yang diujikan benar-benar sesuai dengan konten konsep IPA yang dipelajari siswa. Validasi tes ditetapkan berdasarkan penilaian dan pertimbangan dari tim penilai yang ahli dibidangnya. Validator meliputi dua dosen Program Studi Magister Keguruan IPA FKIP Universitas Lambung Mangkurat, 1 orang dosen Program Studi Kimia FKIP Universitas Lambung Mangkurat, dan dua orang guru mata pelajaran IPA. Tim penilai juga diminta memberikan saran perbaikan jika dianggap perlu.

Berdasarkan hasil validasi dihasilkan soal tes yang valid. Soal tes yang digunakan berbentuk tes pilihan ganda dan uraian sebanyak 13 
Jurnal Inovasi Pendidikan IPA, 3 (1), 2017 - 56

Ikhwan Khairu Sadiqin, Uripto Trisno Santoso, Arif Sholahuddin

soal yang disesuaikan dengan indikator yang ingin dicapai. Teknik penskoran ditentukan dengan rubrik.

\section{Teknik Analisis Data}

Analisis secara kuantitatif dengan teknik analisis statistik deskriptif. Analisis statistik deskriptif adalah statistik yang digunakan untuk menganalisis data dengan cara mendeskripsikan atau menggambarkan data yang telah terkumpul sebagaimana adanya tanpa bermaksud membuat kesimpulan yang berlaku untuk umum atau generalisasi.

Data hasil belajar disajikan secara deskriptif dengan cara melihat perkembangan $n$ gain. Skor pemahaman konsep dari tiap siswa diolah sehingga didapatkan nilai rata-ratanya. Skor rata-rata meliputi skor pretest dan skor posttest. Skor pretest dan posttest digunakan untuk menentukan skor gain dan skor n-gain. berikut.

Rumus penentuan gain adalah sebagai

\section{Gain $=$ Skor posttest - prestest pretest}

Adapun rumus penentuan n-gain adalah sebagai berikut.

$\mathrm{G}=\frac{\text { Gain }}{\text { Skor Ideal-Skor Pretest }}$

Penetapan kategori skor $n$-gain ditampilkan pada Tabel 1.

Tabel 1. Kategori Skor $N$-gain

\begin{tabular}{cc}
\hline Rentang $\langle$ g $>$ & Kategori \\
\hline $0.7 \leq(<\mathrm{g}>) \leq 1,0$ & Tinggi \\
$0.3<(<\mathrm{g}>)<0.7$ & Sedang \\
$0.0<(<\mathrm{g}>) \leq 0.3$ & Rendah \\
\hline
\end{tabular}

Data skor yang dianalisis digolongkan menjadi kategori rendah, sedang dan tinggi berdasarkan dari skor rata-rata siswa yang didapat dari tiap pertemuan. Mengacu pada penetapan kategori ini akan dapat dilihat perkembangan pemahaman konsep siswa menggunakan model problem solving.

\section{HASIL DAN PEMBAHASAN}

Pembelajaran model problem solving menyajikan kesempatan bagi siswa untuk berhadapan dengan pengetahuan berbasis masalah pembelajaran. Siswa dihadapkan pada masalah rutin maupun masalah non rutin. Masalah pembelajaran yang diselesaikan siswa dalam topik perubahan benda-benda di sekitar kita meliputi sifat kimia benda, sifat kimia benda, ciri perubahan fisika, ciri perubahan kimia, prinsip pemisahan filtrasi, prinsip pemisahan sentry- fugasi, prinsip pemisahan kromatografi, prinsip pemisahan destilasi, dan prinsip pemisahan sublimasi. Berdasarkan dari tiap masalah tersebut memiliki konsep-konsep yang perlu dipahami. Pemahaman terhadap konsep-konsep inilah yang dinilai sehingga didapatkan skor rata-rata pemahaman konsep siswa.

Kegiatan pembelajaran tiap tatap muka meliputi siswa diberikan pengantar untuk memberikan motivasi belajar, kemudian siswa diarahkan untuk melakukan kegiatan observasi dan berdiskusi dengan teman kelompoknya dalam proses menemukan konsep dalam masalah.

Terdapat beberapa kegiatan yang dicoba guru terlebih dahulu pada fase observasi. Sebelum siswa diminta untuk melakukan kegiatan observasi secara berkelompok. Hal tersebut untuk menghindari kegagalan dalam percobaan yang dilakukan oleh siswa. Percobaan tersebut meliputi destilasi dan sublimasi pada tatap muka ketiga karena mempertimbangkan pedoman keselamatan praktikum.

Selanjutnya guru bersama siswa menyimpulkan pengertian konsep/definisi serta aplikasinya dalam kehidupan sehari-hari, kegiatan industri, dan kegiatan penelitian di laboratorium. Akhir pembelajaran diadakan evaluasi hasil belajar (Kemendikbud, 2014, p.144).

Data pemahaman konsep sebelum dan sesudah pembelajaran dianalisis dengan cara meninjau nilai rata-ratanya. Perbandingan tingkat pemahaman konsep siswa pada keadaan sebelum dan sesudah pembelajaran disajikan pada Gambar 1.

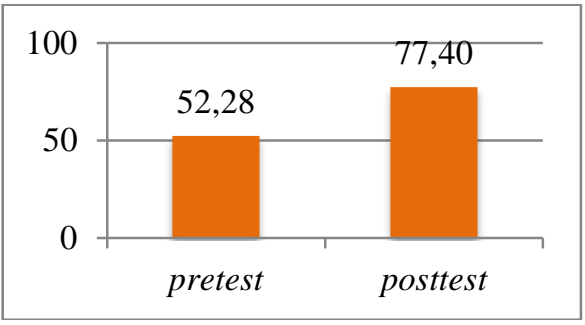

Gambar 1. Persentase Tingkat Pemahaman Konsep Siswa

Berdasarkan rata-rata nilai pemahaman konsep sebelum perlakuan adalah 52,28 atau berada pada kriteria kurang baik. Skor rata-rata sesudah pembelajaran terjadi peningkatan sebesar skor gain yaitu 25,91 poin. Skor setelah dilakukan pembelajaran rata-rata pemahaman konsep siswa meningkat menjadi 77,40 poin atau berada pada kategori baik. Skor n-gain terjadi peningkatan sebesar 0,479 poin atau berada pada kategori sedang. 
Skor pretest tergolong rendah karena dalam keseharian siswa belum terbiasa memecahkan masalah secara sadar. Cenderung canggung karena belum begitu mengenal langkah-langkah pemecahan masalah seperti memahami masalah, merencanakan penyelesaian, menyelesaikan masalah, melakukan pengecekan kembali semua langkah yang telah dikerjakan. Beberapa siswa bahkan belum memahami langkah kegiatan ilmiah dalam menuliskan laporan praktikum. Aspek yang masih sering ditanya siswa pada saat pembelajaran menyangkut merumuskan masalah, memberikan hipotesis, menganalis data, dan menyimpulkan.

Sifat kaku siswa ini membuat mereka mengalami kendala ketika berhadapan dengan beberapa konten masalah. Terutama ketika berhadapan dengan masalah pembelajaran berupa masalah non rutin. Masalah non rutin pada topik perubahan benda-benda di sekitar kita meliputi konsep perubahan fisika, konsep perubahan kimia, konsep pemisahan sentrifugasi, konsep pemisahan kromatografi, dan konsep pemisahan destilasi. Konsep-konsep ini jarang ditemui siswa atau jarang dipikirkan siswa secara lebih sadar. Bahkan dari hasil wawancara disebutkan bahwa sebagian besar siswa baru saja mendengar atau mengenal konsep tersebut.

Adapun ketika telah diajarkan dengan model problem solving siswa diberikan tanggung jawab untuk memecahkan masalah tersebut secara mandiri. Siswa mulai terbiasa dalam melakukan langkah pemecahan masalah. Berbekal pengalaman dalam langkah pemecahan masalah siswa mulai mengetahui apa yang harus dilakukan dalam menuliskan laporan praktikum.

Kesan ini ditandai dengan penurunan jumlah siswa yang minta dipandu dalam langkah penulisan laporan. Frekuensi bertanya pada tatap muka kedua hingga ketiga menurun menandakan siswa mulai mengerti.

Ada dua tanggung jawab yang dibebankan. Pertama laporan pemecahan masalah dalam satu kelompok. Kedua, siswa mendapat kewajiban untuk melaporkan hasil pemecahan masalah secara individu sesuai pemahaman masingmasing dari kerja kelompok tersebut.

Berbekal tanggung jawab tersebut otomatis tiap siswa berlatih dalam memahami masalah, merencanakan penyelesaian masalah, menyelesaikan masalah, melakukan pengecekan kembali semua langkah yang telah dikerjakan. Langkah memahami masalah membuat siswa menyadari lebih mendalam makna masalah. Walaupun mungkin beberapa komponen dalam masalah tersebut sudah perrnah ditemui dalam kehidupan sehari-hari.

Siswa yang memiliki tanggung jawab memecahkan masalah akan memiliki niat yang kuat untuk memahami pelajaran. Sependapat dengan buah pikiran Kelly \& Lovatt (2012, p.646) bahwa siswa yang benar memiliki niat akan berpikir mendalam untuk terlibat dengan pembelajaran, dan beroperasi dalam pemecahan masalah. Dampak lanjutan dari pembiasan kegiatan operasi penyelesaian masalah adalah. pandangan luas dan saling berhubungan satu sama lain antar konten pengetahuan, mudah mengaitkan ide baru dengan pengetahuan sebelumnya.

Secara psikologis, pemahaman konsep mengalami peningkatan karena kegiatan belajar problem solving membuat siswa optimal dalam menyerap serta menghubungkan pengetahuan deklaratif dan pengetahuan prosedural. Pengetahuan awal diperlukan siswa sebagai landasan dalam memecahkan masalah. Pengetahuan awal tersebut sebagian besar tergolong pengetahuan deklaratif dan sebagian kecil tergolong pengetahuan prosedural.

Jenis pengetahuan dapat berupa pengetahuan deklaratif dan pengetahuan prosedural. Pengetahuan deklaratif menyatakan apa sesuatu itu, sedangkan pengetahuan prosedural menyatakan bagaimana melakukan sesuatu itu. Pengetahuan prosedural merupakan tingkatan yang jauh lebih tinggi daripada sekedar pengetahuan deklaratif (Dahar, 2011, p.36).

Jacobsen et.al. (2009, p.249) menyimpulkan bahwa peran guru dalam lingkungan belajar problem solving adalah mengarahkan siswa untuk menemukan informasi yang diperlukan. Siswa dipandu dengan pertanyaan yang jawabannya adalah pengetahuan deklaratif yang diperlukan sebagai prasyarat pemecahan masalah. Jika siswa tidak mampu menemukan pengetahuan tersebut maka guru memberikan arahan dan penyampaian.

Siswa yang terampil dalam menghubungkan dan menganalisis pengetahuan memiliki keunggulan dapat membangun pemahaman. English, Lesh, \& Fennewald (2008, p.9) menemukan bahwa dengan pembelajaran problem solving siswa tidak hanya menghasilkan jawaban, tetapi juga memahami bagaimana proses yang terjadi sehingga jawaban itu bisa didapatnya. Pemahaman yang didapatkan siswa dari hasil pemecahan masalah ini berupa pengetahuan prosedural. 
Jurnal Inovasi Pendidikan IPA, 3 (1), 2017 - 58

Ikhwan Khairu Sadiqin, Uripto Trisno Santoso, Arif Sholahuddin

Intisari riset tersebut memperkuat analisa Winkel dalam Sadiqin, Santoso, \& Sholahuddin, (2016b, p.154) bahwa belajar pemecahan masalah mengakomodasi untuk terimplementasikannya dua dimensi pengetahuan, baik prosedural maupun deklaratif. Kedua jenis pengetahuan tersebut saling berhubungan karena untuk mendapatkan pengetahuan prosedural harus terlebih dahulu memiliki pengetahuan deklaratif sederhana. Saat menghadapi masalah kompleks sejenis masalah non rutin pengetahuan prosedural dikaitkan dengan pengetauan deklaratif lain yang lebih kompeks. Saat pembelajaran siswa menggunakan pemahaman deklaratif yang telah dimiliki untuk memecahkan masalah sehingga pengetahuan prosedural menjadi berkembang.

Semakin mudah pengetahuan deklaratif diserap siswa semakin mudah pula pengetahuan prosedural terbangun di otak siswa. Kombinasi dari pengetahuan prosedural dan pengetahuan deklaratif yang baru didapat siswa terkait masalah membuat siswa mampu merangkum dan membuatnya menjadi pemahaman.

Pemahaman yang didapat siswa dari proses pemecahan masalah menghasilkan pengetahuan prosedural yang jauh lebih kompleks daripada yang dimiliki siswa sebelumnya (Surif, Ibrahim, \& Mokhtar, 2012, p.418). Pengetahuan prosedural baru yang dihasilkan merupakan hasil proses berpikir dari pengetahuan prosedural sebelum pembelajaran. Sesuai dengan pemikiran Charles (2009, p.3) bahwa proses pengumpulan berbagai pengetahuan baru dan kegiatan pemecahan masalah dapat menginisiasi pemahaman. Memperkuat temuan Rubilar, et.al (2013, p.2193) bahwa meramu berbagai pengetahuan konsep dalam memecahkan masalah mendorong berkembangnya pemahaman terhadap konsep IPA lainnya.

Pengetahuan deklaratif dan prosedural diserap dengan baik karena memori kerja pada diri siswa mengalami perluasan cakupan berpikir. Cakupan berpikir mengalami perluasan disebabkan karena siswa terlatih menghubungkan pengetahuan dalam menyelesaikan masalah.

Analisa riset Witt (2012, p.265) membenarkan bahwa semakin sering siswa memecahkan masalah semakin besar cakupan memori kerja pada otak siswa sehingga cakupan berpikir pun ikut berkembang. Ketika bermaksud memecahkan masalah yang belum dipecahkan, siswa berusaha keras mencari informasi yang belum ia dapatkan. Dapat pula siswa mencari kembali informasi yang telah ada dalam memori namun sebelumnya tidak dianggap terkait, padahal sesuai dengan masalah.

Perkembangan cakupan berpikir membuat siswa lebih mudah mengakses infomasi yang diperlukan dalam proses pemecahan masalah berikutnya. Efeknya adalah terampil dalam menemukan solusi. Tiap solusi pemecahan masalah tersebut merupakan pemahaman konsep yang telah terbangun dalam mental siswa (Sadiqin, Santoso, \& Sholahuddin, 2016b, p.154). Berdasarkan proses latihan menghubungkan pengetahuan mulai dari memahami masalah hingga menghasilkan solusi menunjang kemampuan menalar siswa.

Dahar (2011, p.66) menjelaskan kemampuan menalar tersebut ada ketika siswa belajar konsep. Belajar konsep termasuk satu bagian dari 8 bagian bentuk belajar hierarki Gagne. Siswa belajar konsep melalui proses yang dilalui secara bertahap hingga dapat menghasilkan konsep daripada suatu pelajaran. Umumnya setiap konsep yang didapatkan siswa di sekolah merupakan konsep yang tergolong baru baginya. Setiap konsep yang baru dipelajari mensyaratkan proses mental pembentukan konsep.

Proses pembentukan konsep oleh siswa berturut-turut mulai dari mengamati contoh, abstraksi dan diskriminasi contoh, serta penetapan aturan. Proses pertama siswa mengamati objek belajar dengan pancaindra. Proses abstraksi adalah proses mewujudkan perwakilan dari suatu contoh tersebut. Diskriminasi merupakan bentuk belajar dimana siswa mencari perbedaan suatu contoh dari non contoh. Aturan adalah keteraturan dalam situasi khusus. Aturan ini merupakan ketentuan yang menghubungkan objek ke objek lainnya, objek-objek tersebut memiliki sifat saling ketergantungan (Dahar, 2011, p.68).

Contoh aturan sederhana dalam pembelajaran konsep perubahan fisika misalnya jika kayu kering disulut api maka akan terbakar. Objek yang terhubung pada aturan tersebut adalah kayu kering dan api. Aturan atau ketentuan yang menghubungkan kedua objek tersebut adalah kayu kering dapat terbakar jika kayu tersebut disulut api. Proses abtraksi dan diskriminasi yang terjadi adalah siswa harus mengetahui terlebih dahulu bagaimana sifat dan bentuk kayu dan api, perbedaan antara kayu dengan api, dan perbedaan antara kayu basah dan kayu yang tidak basah, karena bisa jadi kayu yang basah tidak terbakar oleh api. Kesimpulan dari suatu aturan menghasilkan pemahaman 
konsep dari informasi yang telah dipelajari siswa tersebut.

Sebagai upaya untuk meninjau lebih dalam tentang kemampuan menalar siswa, dilakukan pula penilaian terhadap kemampuan menalar siswa dalam membentuk konsep. Dahar (2011, p.66) menguraikan bahwa hal ini juga dapat disebut sebagai langkah berpikir pembentukan konsep. Data rata-rata hasil penilaian kemampuan berpikir siswa dalam proses pembentukan konsep disajikan pada Gambar 2.

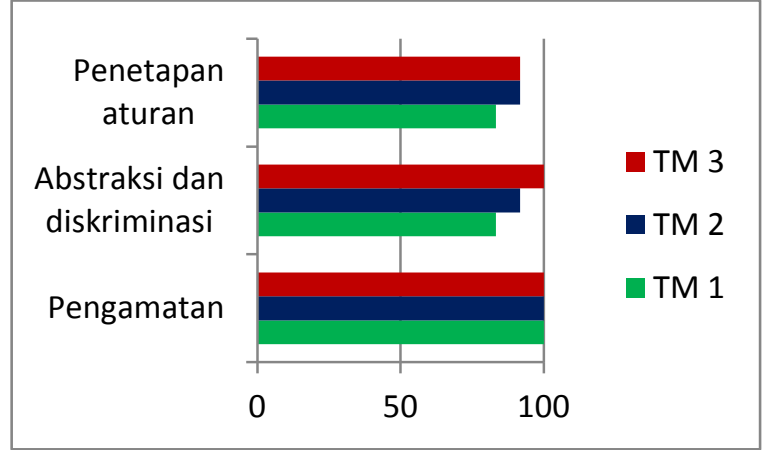

Gambar 2. Persentase Kemampuan Menalar Siswa dalam Membentuk Konsep

Berdasarkan Gambar 2 terlihat bahwa kemampuan siswa dalam membentuk konsep mengalami peningkatan. Kemampuan mengamati berlangsung sangat baik dari tiap tatap muka. Kemampuan abtraksi dan diskriminasi tergolong cukup baik pada awal tatap muka dan mengalami perkembangan hingga tatap muka akhir. Hasil ini linier dengan hasil rata-rata pemahaman konsep siswa yang juga mengalami peningkatan.

Kemampuan mengamati serta abstaksi dan diskriminasi menjadi optimal karena lingkungan belajar problem solving mengharuskan siswa untuk bertanggung jawab menyelesaikan masalah. Langkah awalnya adalah memahami masalah. Perilaku awal yang cenderung dilakukan siswa adalah observasi tentang objek yang menjadi masalah pembelajaran. Hal ini sangat mudah bagi siswa, asal mereka memiliki minat terhadap pembelajaran. Maka dari itu motivasi awal dalam penyajian masalah dalam model problem solving menjadi sangat krusial.

Kemampuan mengamati lebih tinggi daripada kemampuan abtraksi dan diskriminasi terjadi karena proses mengamati cukup dengan panca indra. Tidak banyak membuat otak berpikir untuk memaknai gambaran yang telah ditangkap oleh panca indra. Tetapi ketika berhubungan dengan proses abstraksi dan diskriminasi memerlukan olah pikiran dalam menentukan objek mana yang tergolong contoh dan objek mana yang bukan. Otak bekerja lebih keras untuk memilah informasi tersebut.

Berdasarkan analisis proses mental siswa dalam membentuk pemahaman konsep, lingkungan belajar model problem solving memberikan dampak positif terhadap kemampuan berpikir abstraksi dan diskriminasi.

Berdasarkan Gambar 2 terlihat kemampuan abstraksi dan diskriminasi mengalami perkembangan pada tiap tatap muka. Perkembangan terjadi secara konsisten. Hal ini karena siswa dibiasakan dalam menghubungkan pengetahuan. Pengetahuan tersebut berupa pengetahuan deklaratif dan pengetahuan prosedural. Bermodal pengetahuan deklaratif dan pengetahuan prosedural yang telah tersedia siswa memilah kembali antara pengetahuan yang sesuai dengan contoh dan pengetahuan yang tidak sesuai contoh. Ketika siswa sudah sampai pada keadaan ini, memudahkan untuk memilah informasi penting terkait makna masalah pembelajaran yang disajikan, proses pemecahan masalah, hingga penetapan kesimpulan pemecahan masalah.

Keterampilan memilah informasi ini mengoptimalkan siswa dalam menganalisis hubungan tiap pengetahuan yang sudah dimiliki dalam penetapan aturan. Aturan yang dimaksud adalah kunci atau pola jawaban pada permasalahan atau soal. Jika siswa sudah mengetahui suatu pola jawaban, akan memudahkan dalam memahami konsep lain yang mirip. Keadaan ini dapat dilihat seperti contoh pembahasan siswa dalam menjawab LKS tentang konsep perubahan fisika pada Gambar 3.

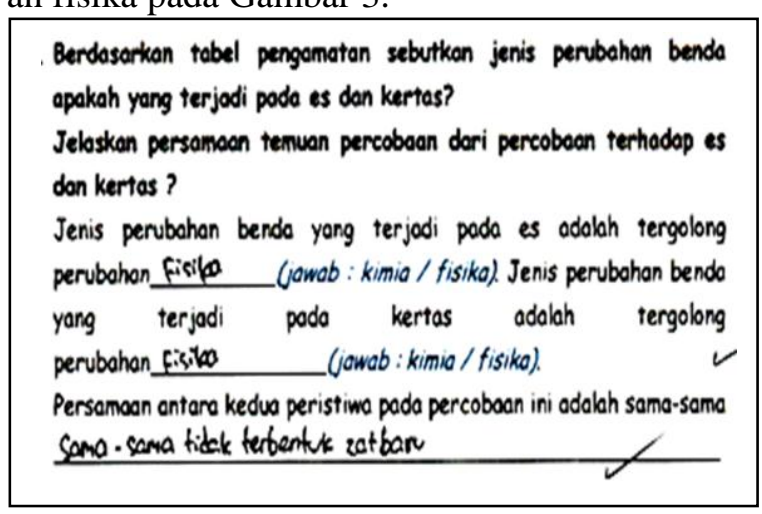

Gambar 3. Lembar Jawaban Siswa

Merujuk Gambar 3 siswa telah mampu mengadakan proses mengamati objek percobaan dengan baik yakni tentang peristiwa melelehnya es dan perubahan bentuk pada kertas yang dilipat. Berhasil pula melakukan abstraksi dan diskriminasi sehingga dapat menyimpulkan bahwa kedua peristiwa tersebut termasuk perubahan fisika. Berbekal dua pengetahuan tersebut siswa 
dapat terbantu dalam menentukan aturan yang mengikat kedua peristiwa tersebut yakni samasama tidak terbentuk zat baru.

Berdasarkan data pada Gambar 2 kemampuan penetapan aturan tergolong baik namun tidak optimal layaknya kemampuan mengamati serta abstaksi dan diskriminasi. Hal ini wajar terjadi mengingat kemampuan penetapan aturan merupakan proses akhir dalam menyelesaikan masalah. Kemampuan penetapan aturan sangat bergantung pada dua proses awal terdahulu. Jika dua proses awal tidak berjalan dengan mulus, maka tahap akhir pembentukan konsep ini tidak akan lebih baik dari yang lain. Apabila dalam proses mengamati serta abstraksi dan diskriminasi siswa mengalami kesalahan, hasil penetapan aturan menjadi keliru.

Secara umum dapat disimpulkan tiga proses mental membentuk konsep terlatih dengan baik. Dampak akhirnya adalah siswa dapat membangun pemahaman konsep baru dengan berbekal pengetahuan prosedural dan pengetahuan deklaratif yang telah dihubungkan. Perbendaharaan pemahaman konsep siswa menjadi lebih berkembang. Perubahan positif lain yang dapat terjadi adalah siswa memperbaharui pemahaman yang telah ada sehingga menjadi lebih lengkap atau sahih.

Dampak dari proses pemecahan masalah tersebut berkesesuaian dengan teori konstruktivis yang dicetuskan oleh Piaget. Piaget menekankan bahwa siswa membangun pengetahuannya melalui serangkaian proses belajar. Berdasarkan proses memilah pengetahuan, apabila cocok antara peristiwa baru didapat dengan skema yang telah ada tergolong proses asimilasi (Slavin, 2011, p.43). Apabila tidak cocok akan terjadi akomodasi. Asimilasi maupun akomodasi merupakan indikasi konkret bahwa pemahaman konsep siswa telah mengalami perkembangan.

Hasil penelitian ini mendukung laporan penelitian terdahulu. Gok \& Silay (2010, p.7), Samuel (2013, p.46) dan Jackson \& Martin (2014, p.25) menyatakan bahwa pemahaman konsep siswa mengalami peningkatan melalui pembelajaran problem solving. Capobianco \& Tyrie (2009, p.41) menyampaikan siswa memiliki potensi lebih dalam menciptakan opsi cara menyelesaikan masalah, mengembangkan pemahaman baru, dan menambah kemampuan untuk memahami suatu masalah secara mendalam.

\section{SIMPULAN}

Pemahaman konsep siswa kelas VII SMP Negeri 1 Banjarmasin dan SMP Negeri 1
Banjarbaru dengan menggunakan model pembelajaran problem solving pada topik perubahan benda di sekitar kita mengalami peningkatan yaitu dengan skor pretest sebesar 52,28 \% dan skor posttest sebesar $77,40 \%$. Peningkatan pemahaman konsep dipicu oleh perkembangan kemampuan menalar siswa dalam membentuk konsep yakni kemampuan abstaksi dan diskriminasi. Kemampuan abstaksi dan diskriminasi yang optimal memudahkan siswa untuk menghubungkan berbagai pengetahuan prosedural dan pengetahuan deklaratif yang diperlukan dalam memecahkan masalah pembelajaran.

\section{DAFTAR PUSTAKA}

Ali, R., Hukamdad, Akhter, A \& Khan, A. (2010). Effect of using problem solving method in teaching mathematics on the achievement of mathematics students. Journal Asian Social Science, 6 (2), 6772.

Arafah, H., \& Sihes, A. J. B. (2015). Competencies for the classroom instructional designer. International Journal of Secondary Education, 3 (2), 16-20.

Arends, R. (2012). Learning to teach. ( $9^{\text {th }}$ ed.). New York: McGraw-Hill Companies Inc.

Capobianco, B. M., \& Tyrie, N. (2009). Problem solving using design. Science and Children, 47 (2), 38-41.

Charles, R. (2009). The role of problem solving in high school mathematics. New Jersey: Pearson Education.

Coştu, B. (2008). Learning science through the PDEODE teaching strategy: helping students make sense of everyday situations. Eurasia Journal of Mathematics, Science \& Technology Education, 4 (1), 3-9.

Dahar, R. W. (2011). Teori-teori belajar \& pembelajaran. Jakarta: Erlangga.

English, L. D., Lesh, R \& Fennewald, T. (2008). Future directions and perspectives for problem solving research and curriculum development. Prosiding 11th International Congress on Mathematical Education yang diselenggarakan oleh International Mathematical Union, tanggal 6-13 Juli 2008. Monterrey.

Gok, T., \& Silay, I. (2010). The effects of problem solving strategies on students' 
achievement, attitude and motivation. Lat. Am. J. Phys. Educ, 4 (1), 7-21.

Gupta, M., Kavita \& Pasrija, P. (2016). Problem solving ability \& locality as the influential factors of academic achievement among high school students. Issues and Ideas in Education, 4 (1), 37-50.

Holme, T. A., Luxford, C. J \& Brandriet, A. (2015). Defining conceptual understanding in general chemistry. Journal of Chemical Education, 92 (9), 1477-1483.

Jackson, K, M \& Martin, S, M, W. (2014). Effect of problem solving strategy on secondary school students achievement in circle geometry in emuhaya district of vihiga county. Journal of Education, Arts and Humanities, 2 (2), 18-26.

Jacobsen, D.A., Eggen, P., \& Kauchak, D. (2009). Methods for teaching: metodemetode pengajaran meningkatkan hasil belajar siswa TK-SMA. (Terjemahan Achmad Fawaid \& Khoirul Anam). Yogyakarta: Pustaka Pelajar.

James, A. O. (2012). Relationship between senior secondary schools students' achievement in mathematical problemsolving and intellectual abilities tests. European Scientific Journal, 8 (15), 169179.

Kelly,O., \& Lovatt, J. (2012) Insights into science students' problem-solving strategies in the chemistry laboratory. Pixel, 47 (6), 643-660. Retrieved from http://eprints.teachingandlearning.ie/2655/

Kemendikbud. (2013). Peraturan menteri pendidikan dan kebudayaan nomor 65 tahun 2013. Jakarta: Kementerian Pendidikan dan Kebudayaan.

Kemendikbud. (2014). Buku guru ilmu pengetahuan alam edisi revisi. Jakarta: Kementerian Pendidikan dan Kebudayaan.

Nfon, N. F. (2013). Effect of rusbult's problem solving strategy on secondary school students achievement in trigonometry classroom. Journal of Mathematics Education, 6 (1), 38-55.

OECD. (2016). PISA 2015 Results in focus. Paris: OECD Publishing,

Perveen, K. (2010). Effect of the problem solving approach on academic achievement of students in mathematics at the secondary level. Contemporary Issues In Education Research, 3, (3), 9-14.

Rubilar, C. M., Jara, R., Leyton, P., Paipa, C \& Izquierdoc, M. (2013). Designing problems to learn chemistry: A toulminian approach. Procedia - Social and Behavioral Sciences, 116, 21932197.

Sadiqin, I. K. (2015). Keterampilan berpikir kritis dan hasil belajar siswa kelas VII MTs pondok pesantren modern banjarmasin dengan model problem solving. Prosiding Seminar Nasional Pendidikan Sains yang diselenggarakan oleh Pascasarjana Unesa, tanggal 24 Januari 2015. Surabaya: Pascasarjana Unesa.

Sadiqin, I, K., Santoso, U, T., \& Sholahuddin, A. (2016a). Problem solving-based learning tools to improve the science problem solving skills of junior high school. Prosiding International Conference On Educational Research and Innovation yang diselenggarakan oleh LPPM UNY, tanggal 11-12 mei 2016. Yogyakarta: Institute of Research and Community Services Yogyakarta State University.

Sadiqin, I, K., Santoso, U, T., \& Sholahuddin, A. (2016b). Keterampilan memecahkan masalah IPA siswa SMPN 1 banjarmasin melalui pembelajaran problem solving pada topik perubahan benda-benda di sekitar kita. Prosiding Seminar Nasional Pendidikan IPA yang diselenggarakan oleh Program Studi Magister Keguruan IPA ULM, Pendidikan IPA ULM dan Perkumpulan Pendidik IPA Indonesia, tanggal 3 September 2016. Banjarmasin: S2 IPA UNLAM Press.

Samuel, O. N. (2013). Effect of polya george's problem solving model on students'achievement and retention in algebra. Journal of Educational and Social Research, 3 (6), 41-48.

Setiadi, H., Mahdiansyah., Suryaman, M., Afiani, E., \& Rahmawati. (2012). Analisis hasil belajar peserta didik dalam literasi membaca melalui studi internasional PIRLS 2011. Jakarta: Pusat Penilaian Pendidikan Balitbang Kemendikbud. 
Jurnal Inovasi Pendidikan IPA, 3 (1), 2017 - 62

Ikhwan Khairu Sadiqin, Uripto Trisno Santoso, Arif Sholahuddin

Slavin, R. (2011). Psikologi pendidikan teori dan praktik jilid I. (Terjemahan Marianto Samosir) Jakarta: Indeks

Sugiyono. (2012). Metode penelitian kuantitatif, kualitatif dan $R \& D$. Bandung: Alfabeta.

Surif, J., Ibrahim, N, H., \& Mokhtar, M. (2012). Conceptual and procedural knowledge in problem solving. Procedia Social and Behavioral Sciences, 56, 416-425.

Tafsir, A. (2012). Filsafat Pendidikan Islami. Bandung: Rosdakarya.
Wasis. (2015). Hasil pembelajaran sains di indonesia: problem \& upaya mengatasinya. Prosiding Seminar Nasional Pendidikan Sains yang diselenggarakan oleh Pascasarjana Unesa, tanggal 24 Januari 2015. Surabaya: Pascasarjana Unesa.

Witt, M. (2012). The impact of mathematics anxiety on primary school children's working memory. Europe's Journal of Psychology, 8 (2), 263-274. 